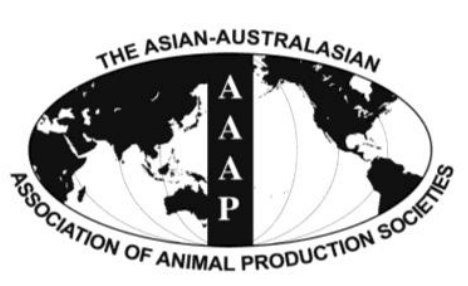

Open Access

Asian Australas. J. Anim. Sci.

Vol. 27, No. 5 : 683-689 May 2014

http://dx.doi.org/10.5713/ajas.2012.12543

pISSN 1011-2367 elSSN 1976-5517

\title{
Pig Feeding under the Potato-green Forage Base System with or without Addition of Herbs versus a Concentrate Based System: Effect on Post-slaughter Performance and Pork Characteristics
}

\author{
Zofia Turyk, Maria Osek, Boguslaw Olkowski*, and Alina Janocha \\ Institute of Bioengineering and Animal Breeding, Faculty of Life Sciences, \\ University of Natural Science and Humanities in Siedlce, 14 B. Prusa Street, 08-110 Siedlce, Poland
}

\begin{abstract}
This study examined carcass and meat quality parameters in growing/finishing pigs fed unconventionally versus the concentrate-based system. Ninety-six, 12 wk old pigs $(34 \pm \mathrm{SD} 0.3 \mathrm{~kg}$ ) were randomly divided into three groups, assigned to one of the three dietary treatments: standard complete concentrate mixture, conventional (C diet); unconventional, steamed potato-green forageconcentrate based diet ( $\mathrm{U}$ diet), and unconventional basal diet+herbage mix (UH diet). Pigs fed $\mathrm{U}$ diet showed lower dressing percentage, meatiness, loin eye area, and weight of pork neck $(\mathrm{p} \leq 0.05)$, but their carcasses were significantly $(\mathrm{p} \leq 0.05)$ longer and had increased backfat depth $(\mathrm{p} \leq 0.05)$. There was no impact of the diet on the meat content of dry matter, crude ash, acidity, and colour parameters of $m$. longissimus. Unconventional feeding significantly $(\mathrm{p} \leq 0.05)$ elevated water the holding capacity of $m$. longissimus and slightly improved the sensory attributes analysis of meat. The addition of herbs resulted in increased loin eye area ( $\mathrm{p} \leq 0.05)$, decreased fat content $(\mathrm{p} \leq 0.05)$ in $m$. longissimus, and tended to improve some sensory attributes of meat. There were significant gender differences in response to all diets. There were significant diet $\times$ sex interactions for some measured variables, but there were no clearly identifiable trends with regard to any specific carcass or meat parameters. Feeding unconventional diet to pigs may offer better culinary attributes of the meat, and improve some technologically important characteristics of pig carcass, but may negatively affect some carcass or meat parameters. (Key Words: Swine, Potato-green Forage-concentrate Mixture, Complete Mixture, Herbage, Carcass, Meat)
\end{abstract}

\section{INTRODUCTION}

Consumers' interest in food qualities such as high dietetic and health values has been increasing in recent years. With regard to pork, such qualities can be obtained by supplementation of diets for growing/finishing pigs with different herbal mixtures based on: lemon balm, peppermint, nettle, thyme, couch grass, garlic, purple coneflower, rosemary, oregano, and ginger (Grela, 2000; Krusiński, 2000; Hańczakowska et al., 2007; Janz et al., 2007).

The most desired attributes of meat quality taken into account by the customer include the overall appearance,

* Corresponding Author: B. Olkowski. Tel: +48-25-6431249, Fax: +48-25-6431267, E-mail: b.olkowski@ap.siedlce.pl Submitted Oct. 3, 2012; Revised Dec. 19, 2012; Accepted Jan. 8, 2014 colour, as well as sensory properties such as flavour, juiciness, and tenderness (Bredahl et al., 1998; Bryhni et al., 2002). Quality is an important factor in consumer's decision to purchase the meat (Kim et al., 1999).

Large scale production of growing/finishing pigs (conventional pork production systems) is commonly based on bulk commercial concentrate mixtures, which may affect meat quality due to limited dietary ingredient selection. On the other hand, strategic feeding offers high potential for the control of pork quality (Rosenvold et al., 2001; Bee et al., 2006)

Inclusion of vegetables such as potatoes or green roughage fodder may have beneficial effects on both animals health and meat quality. In particular, potatoes as a dietary ingredient rich in starch and relatively low in protein offer high biological value and good digestibility (Jentsch, 
1992). Potato protein reduces the quantity of pathogenic bacteria in excreta, which is of particular importance in the context of the ban on an application of antibiotics (Jin et al., 2008). Intake of green roughage has been shown to have significant positive effect on meat sensory attributes such as tenderness and taste (Danielsen et al., 2000). Also roughages may positively affect the development of the intestinal micro flora and mucosal health. Roughages can be used in the diet up to $18 \%-19 \%$ of dry matter for pigs over $60 \mathrm{~kg}$ with no effect on feed acceptance by the animals (Carlsson et al., 1999).

Improved utilization of feed and better meat quality may be obtained by dietary inclusion of herbs such as: garlic, rosemary, lemon balm, peppermint, nettle, thyme, and couch grass (Cullen et al., 2005; Świątkiewicz and Hańczakowska, 2008) and thyme, chamomile, mint, coriander which also may reduce the amount of ammonia in piggeries (Paschma et al., 2010).

At present most swine operations use grain based industrial concentrate mixtures containing barley and triticale for broad application in pig fattening (Turyk et al., 2011).

However, there is a paucity of information on application of forages/roughages in diets for growing/finishing pigs. Thus our interest was to evaluate the potato-based feeding system supplemented with concentrates and herbs on post-slaughter performance and pork characteristics.

\section{MATERIAL AND METHODS}

Ninety six, 12-wk-old piglets (Polish Synthetic Line of 990 [Borzuta et al., 2008] $\times$ Polish White Large) with a mean BW of $34 \mathrm{~kg}$ (SD $0.3 \mathrm{~kg}$ ) were randomly divided into three groups (32 animals per groups), and assigned to one of the three dietary treatments: conventional $(\mathrm{C})$, unconventional (U), and unconventional with herbs (UH). Group C was fed a diet comprising standard complete concentrate mixture, group U was fed diet based on steamed potato-green forageconcentrate mixture, and group UH was offered the same basal diet as group U, but supplemented with herbal mix (X-tract Provit Kutno, Poland) (Table 1). Each diet was formulated (Table 2) to meet nutritional requirements (NZS, 1993) and offered in the form of wetted meal to the respective group in equal portions twice per day. Water was provided ad libitum. Pigs were raised using a two-phase dietary feeding program where the first-phase diets were fed for 41 days and second-phase diets were fed for 28 days. The animals of each group were kept in pens on straw bedding. After the second phase, 16 animals ( 8 males and 8 females) with BW close to the average BW in each group were slaughtered. Immediately after the slaughter, lean percentage was tested using the DRAMINSKI electroniclinear device (http://www. draminski.com) calculated on the basis of a regression equation ( $\mathrm{Y}=52.61-0.6148 \mathrm{~T}+$ $0.1842 \mathrm{M})$, based on measurement of: $\mathrm{T}=$ back fat thickness above the mid-part and edge of the gluteal muscle (loin I

Table 1. Ingredients of the experimental diets (\%)

\begin{tabular}{|c|c|c|c|c|c|c|}
\hline \multirow{3}{*}{ Items } & \multicolumn{6}{|c|}{ Treatments/diets } \\
\hline & \multicolumn{2}{|c|}{$\mathrm{C}$ (Conventional) } & \multicolumn{2}{|c|}{ U (Unconventional) } & \multicolumn{2}{|c|}{ UH (U+herbs) } \\
\hline & Starter & Grower & Starter & Grower & Starter & Grower \\
\hline Barley & 32.33 & 30.23 & 35.78 & 36.54 & 35.78 & 36.54 \\
\hline Wheat & 30.82 & 20.61 & - & - & - & - \\
\hline Triticale (\%) & 10.19 & 20.61 & - & - & - & - \\
\hline Soy bean meal solvent ext. (42\% CP) & - & 15.80 & 11.01 & 8.60 & 11.01 & 8.60 \\
\hline Soy bean meal solvent ext. ( $48 \% \mathrm{CP})$ & 8.42 & - & - & - & - & - \\
\hline Wheat middlings & 5.31 & 10.31 & - & - & - & - \\
\hline Fish meal $(56 \% \mathrm{CP})$ & 5.31 & - & - & - & - & - \\
\hline Porcine blood dried (75\% CP) & 2.66 & - & - & - & 0.0 & - \\
\hline Soya oil & 2.66 & - & 1.76 & - & 1.76 & - \\
\hline Vitamin-mineral suplement ${ }^{1}$ & 2.30 & 2.44 & 1.90 & 1.14 & 1.90 & 1.14 \\
\hline Potatoes steamed (average DM 21.5\%) & - & - & 35.78 & 42.98 & 35.78 & 42.98 \\
\hline Grass forage $^{2}$ (average DM 19.2\%) & - & - & 13.76 & 10.75 & 13.76 & 10.75 \\
\hline Herbs mixture $^{3}(\mathrm{mg})$ & - & - & - & - & 650 & 850 \\
\hline
\end{tabular}

${ }^{1}$ Starter: provided per pig/d: Vitamin A, 21,000 IU; Vitamin $\mathrm{D}_{3}$, 4,200 IU; Vitamin E, 117.6 mg; Vitamin K, 2.52 mg; Riboflavin, 8.4 mg; Calcium pantothenic acid, $42 \mathrm{mg}$; Niacin, $33.6 \mathrm{mg}$; Biotin, $168 \mu \mathrm{g}$; Vitamin $\mathrm{B}_{12}, 42 \mu \mathrm{g}$; Fe, $159.6 \mathrm{mg}$; Cu, $42 \mathrm{mg} ; \mathrm{Zn}, 160 \mathrm{mg}$; Mn, $69.1 \mathrm{mg}$; I, $2.1 \mathrm{mg}$; Se, 0.53 mg. Lysine (synthetic), $1.5 \mathrm{~g} ; \mathrm{NaCl}, 2.1 \mathrm{~g} ; \mathrm{Ca}, 8 \mathrm{~g} ; \mathrm{P}, 2.3 \mathrm{~g}$. Ca and $\mathrm{P}$ were supplemented with limestone and dicalcium phosphate.

Grower: provided per pig/d: Vitamin A, 26,000 IU; Vitamin $\mathrm{D}_{3}$, 5,500 IU; Vitamin E $275 \mathrm{mg}$; Vitamin $\mathrm{K}_{3}$, $4.5 \mathrm{mg}$; Riboflavin, $10.3 \mathrm{mg}$; Calcium

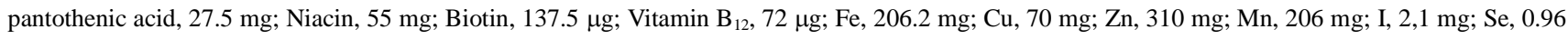
$\mathrm{mg} ; \mathrm{NaCl}, 2.1 \mathrm{~g} ; \mathrm{Ca}, 9.5 \mathrm{~g}$. Ca and $\mathrm{P}$ were supplemented with limestone and dicalcium phosphate.

${ }^{2}$ Daily cuts green forage mixture: ryegrass, red clover, white clover, lucerne.

${ }^{3}$ Herbs extracts: X-tract ${ }^{\mathrm{TM}}$ Provit Kutno, Poland, (Mexican pepper, Cinamon, Oregano). 
Table 2. Daily rations and nutritive value of diets

\begin{tabular}{|c|c|c|c|c|c|c|}
\hline \multirow{3}{*}{ Items } & \multicolumn{6}{|c|}{ Treatments } \\
\hline & \multicolumn{2}{|c|}{$\mathrm{C}$ (Conventional) } & \multicolumn{2}{|c|}{ U (Unconventional) } & \multicolumn{2}{|c|}{ UH (U+herbs) } \\
\hline & Starter & Grower & Starter & Grower & Starter & Grower \\
\hline Daily rations $(\mathrm{kg})$ & 2.26 & 2.87 & 3.50 & 4.60 & 3.50 & 4.60 \\
\hline \multicolumn{7}{|l|}{ Nutritional value per $1 \mathrm{~kg}$ of diet } \\
\hline Metabolizable energy (MJ) & 12.87 & 11.96 & 7.99 & 7.33 & 7.99 & 7.33 \\
\hline Digestible protein $(\mathrm{g})$ & 125.5 & 116.6 & 78.2 & 71.4 & 78.2 & 71.4 \\
\hline Lysine $(\mathrm{g})$ & 8.4 & 7.3 & 5.4 & 4.4 & 5.4 & 4.4 \\
\hline Methionine+cysteine (g) & 5.7 & 5.5 & 3.2 & 3.0 & 3.2 & 3.0 \\
\hline Calcium $(\mathrm{g})$ & 7.0 & 5.4 & 4.2 & 3.4 & 4.2 & 3.4 \\
\hline Available phosphorus (g) & 2.1 & 1.9 & 1.2 & 1.1 & 1.2 & 1.1 \\
\hline
\end{tabular}

and II), and $\mathrm{M}=$ the distance between the ending of the gluteal muscle and the upper edge of the medullar canal, at the level of loin I. Acidity measurements of meat were performed using Mettler Toledo $\mathrm{pH}$ meter (SG8-ELK). First recording of $m$. longissimus was obtained 45 minutes after slaughter $\left(\mathrm{pH}_{45} \mathrm{~min}\right)$. Next, the carcasses were placed in the chilling room at the temperature $2^{\circ} \mathrm{C}$ to $4^{\circ} \mathrm{C}$, and second recording of acidity ( $\mathrm{pH}_{24}$ hours) was performed 24 hours after the first recording of acidity. The carcass length, belly thickness, and height and width of loin eye were measured using the right halves of each carcass. Carcass length was measured from the anterior edge of the symphysis pubis to the recess of the first rib.

The belly thickness was measured at the level of cut between two carcass halves using a slide calliper. The measurements were carried out in five locations: above the shoulder, mid back (between the last thoracic vertebra and the first lumbar vertebrae) and over loin (at the level of sacral vertebrae: I, II, III). The width of loin eye was measured at the widest point of the eye muscle, and the height of the eye at the highest part of the section, which was measured at the right angle to the width. Samples of $m$. longissimus lumborum and $m$. semimembranosus were taken from each half carcass to analyze physical and chemical characteristics. The contents of DM, crude ash, CP and crude fat in meat samples were analyzed according to (AOAC, 1990), and the intensity of colour (CIE L*a*b) using Minolta Chroma Meter CR-310. Meat samples were also subjected to water holding capacity (WHC) analysis, determined as the amount of free water using the filter paper press method Grau and Hamm (1953) as described by Majewska et al. (2009).

The sensory evaluation was conducted by a 10 -member testing panel of trained analysts. A 5-point scale (from 1, least favourable to 5, most favourable) was used to evaluate flavor, juiciness, tenderness, and palatability of cooked meat of longissimus lumborum.

\section{Statistical analysis}

Caracass data was collected from individual animals resulting in 16 observations including 8 male and 8 females per treatment. Data were analyzed as a complete randomized block design using general linear model (GLM). Individual pigs were considered as the experimental unit. Analysis of variance (ANOVA) was performed in order to evaluate the effect of diet on carcass and meat quality traits. The model comprised fixed effects of treatment group (A), gender (B) and interaction $\mathrm{A} \times \mathrm{B}$.

$$
Y_{i j}=\mu+A_{i}+B_{j}+A_{i j}+e_{i j}
$$

Where:

$Y_{i j}=$ value for measurement; $\mu=$ population mean; $A_{i}=$ fixed effect of group (diet); $B_{j}=$ fixed effect of gender; $A_{i j}$ $=$ interaction between group and gender effects; $\mathrm{e}_{\mathrm{ij}}=$ error of term.

Data are presented as means and pooled standard error (SEM). When significant effects were detected $(p<0.05)$, Tukey's test was used to compare means. All data were analyzed using the computer package NCSS.

\section{RESULTS AND DISCUSSION}

There were no significant difference in BW at slaughter (Table 3). There were no effects of diets on ham and shoulder weight. However, unconventionally fed pigs (Group U) had a lower dressing percentage $(\mathrm{p} \leq 0.05)$, meatiness $(p \leq 0.05)$, and loin eye area $(p \leq 0.05)$, but their carcasses were significantly $(\mathrm{p} \leq 0.05)$ longer in comparison to group C. Feeding the unconventional diet also reduced $(\mathrm{p} \leq 0.05)$ the weight of pork neck $(\sim 5 \%)$ although it did not influence the weight of shoulder and ham. Interestingly, pigs fed unconventional based diets (U and $\mathrm{UH}$ ) stored more fat, with the suet fat weight in group fed UH diet being $27 \%$ higher in comparison to group fed diet $\mathrm{C}$. However, pigs fed conventional diet had significantly thicker backfat $(\mathrm{p} \leq 0.05)$ on the shoulder and back. Also, pigs fed conventional diet showed higher meatiness, loin eye area, and shoulder weight (all $\mathrm{p} \leq 0.05$ ). Of note, gilts fed 
Table 3. Results of slaughter value of fatteners

\begin{tabular}{|c|c|c|c|c|c|c|c|c|c|c|}
\hline \multirow{3}{*}{ Specification } & \multicolumn{6}{|c|}{ Treatment (Diet/sex) } & \multirow{3}{*}{ SEM } & \multicolumn{3}{|c|}{ Significance } \\
\hline & \multicolumn{2}{|c|}{$\mathrm{C}$ (Conventional) } & \multicolumn{2}{|c|}{ U (Unconventional) } & \multicolumn{2}{|c|}{ UH (U+herbs) } & & \multirow{2}{*}{ Diet (D) } & \multirow{2}{*}{$\operatorname{Sex}(S)$} & \multirow{2}{*}{$\mathrm{D} \times \mathrm{S}$} \\
\hline & $\mathrm{G}^{1}$ & $\mathrm{~B}^{1}$ & $\mathrm{G}$ & $\mathrm{B}$ & $\mathrm{G}$ & $\mathrm{B}$ & & & & \\
\hline Slaughter BW (kg) & 107.0 & 108.5 & 107.1 & 107.8 & 107.1 & 106.8 & 0.346 & 0.196 & 0.116 & 0.122 \\
\hline Dressing percentage $(\%)$ & $78.6^{\mathrm{a}}$ & $79.3^{\mathrm{a}}$ & $81.3^{\mathrm{b}}$ & $81.8^{\mathrm{b}}$ & $81.9^{\mathrm{b}}$ & $82.8^{\mathrm{b}}$ & 0.570 & 0.006 & 0.001 & 0.009 \\
\hline Internal carcass length $(\mathrm{cm})$ & $83.4^{\mathrm{a}}$ & $83.8^{\mathrm{a}}$ & $86.3^{\mathrm{b}}$ & $84.5^{\mathrm{a}}$ & $84.6^{\mathrm{a}}$ & $84.7^{\mathrm{a}}$ & 0.446 & 0.001 & 0.148 & 0.007 \\
\hline Meatness $(\%)$ & $59.1^{\mathrm{d}}$ & $56.3 \mathrm{c}$ & $56.7^{\mathrm{c}}$ & $52.8^{\mathrm{a}}$ & $56.3^{\mathrm{b}}$ & $53.6^{\mathrm{a}}$ & 0.346 & 0.001 & 0.001 & 0.437 \\
\hline Loin eye area $\left(\mathrm{cm}^{2}\right)$ & $50.3^{\mathrm{c}}$ & $44.8^{\mathrm{b}}$ & $38.6^{\mathrm{a}}$ & $38.1^{\mathrm{a}}$ & $43.9^{b}$ & $43.8^{b}$ & 1.16 & 0.001 & 0.035 & 0.045 \\
\hline Ham weight (kg) & 8.0 & 8.1 & 7.8 & 8.0 & 7.9 & 7.9 & 0.212 & 0.724 & 0.573 & 0.909 \\
\hline Shoulder weight $(\mathrm{kg})$ & 7.4 & 6.6 & 7.4 & 7.4 & 7.5 & 7.3 & 0.178 & 0.112 & 0.014 & 0.104 \\
\hline Neck weight $(\mathrm{kg})$ & 3.29 & 3.30 & 3.16 & 3.11 & 3.18 & 3.03 & 0.070 & 0.020 & 0.228 & 0.518 \\
\hline Suet weight (kg) & $1.06^{\mathrm{a}}$ & $1.73^{\mathrm{b}}$ & $1.58^{\mathrm{b}}$ & $1.62^{\mathrm{b}}$ & $1.51^{\mathrm{b}}$ & $2.03^{\mathrm{c}}$ & 0.062 & 0.001 & 0.001 & 0.001 \\
\hline \multicolumn{11}{|l|}{ Backfat depth (mm) } \\
\hline Over the shoulder & $29.8^{\mathrm{a}}$ & $34.3^{\mathrm{b}}$ & $37.3^{\mathrm{b}}$ & $38.8^{\mathrm{bc}}$ & $40.6^{\mathrm{c}}$ & $37.8^{\mathrm{b}}$ & 0.885 & 0.001 & 0.064 & 0.001 \\
\hline Mid back & $25.0^{\mathrm{a}}$ & $26.0^{\mathrm{a}}$ & $26.5^{\mathrm{ab}}$ & $29.5^{\mathrm{c}}$ & $29.0^{\mathrm{b}}$ & $27.3^{\mathrm{abc}}$ & 0.774 & 0.002 & 0.242 & 0.014 \\
\hline Sacrum I & $27.5^{\mathrm{b}}$ & $21.3^{\mathrm{a}}$ & $24.5^{\mathrm{ab}}$ & $22.3^{\mathrm{ab}}$ & $27.1^{\mathrm{c}}$ & $27.5^{\mathrm{c}}$ & 0.862 & 0.001 & 0.146 & 0.317 \\
\hline Sacrum II & $27.8^{\mathrm{ab}}$ & $25.0^{\mathrm{a}}$ & $28.7^{\mathrm{ab}}$ & $27.8^{\mathrm{ab}}$ & $26.8^{\mathrm{ab}}$ & $30.5^{\mathrm{b}}$ & 0.970 & 0.056 & 0.001 & 0.005 \\
\hline Sacrum III & $31.8^{\mathrm{b}}$ & $28.3^{\mathrm{a}}$ & $33.0^{\mathrm{b}}$ & $33.0^{\mathrm{b}}$ & $31.8^{\mathrm{b}}$ & $33.0^{\mathrm{b}}$ & 0.907 & 0.001 & 0.151 & 0.042 \\
\hline Average 5 measurement & $27.4^{\mathrm{a}}$ & $27.0^{\mathrm{a}}$ & $30.2 b^{c}$ & $30.5^{\mathrm{bc}}$ & $30.9^{\mathrm{c}}$ & $31.2^{\mathrm{c}}$ & 0.568 & 0.001 & 0.957 & 0.811 \\
\hline
\end{tabular}

${ }^{1} \mathrm{G}=$ Gilts $(\mathrm{n}=8)$; $\mathrm{B}=$ Barrows $(\mathrm{n}=8) .{ }^{\mathrm{a}, \mathrm{b}, \mathrm{c}}$ Means in columns with a similar letter did not differ $\mathrm{p} \leq 0.05$.

$\mathrm{U}$ diet showed significantly $(\mathrm{p} \leq 0.05)$ longer carcass.

Decreased meatiness in pigs fed the unconventional diet observed in our study may have resulted from high levels of potatoes included in the diet. Reduced slaughter performance and meatiness in the carcasses of unconventionally fed pigs observed in the present study are consistent with the results of Buczma (2000). Also, the effect of herb's supplement on increased loin eye area is in agreement with the results reported by Paschma and Wawrzyński (2007).

There were significant gender differences and diet $\times$ gender interactions for some variables in response to all diets, but there were no clearly identifiable trends with regard to any specific carcass or meat parameters (Table 3). Furthermore, neither feeding regime (diet) nor gender affected the acidity level, colour parameters and crude ash content of $\mathrm{m}$. longissimus (Table 4). There were significant interactions between diet and sex for content of $\mathrm{CP}(\mathrm{p}<0.05)$ and crude fat $(\mathrm{p}<0.001)$. Also, diets have a significant impact on WHC $(\mathrm{p}<0.001)$, CP $(\mathrm{p}<0.04)$ and crude fat $(\mathrm{p}<0.02)$ content in $m$. longisimus muscle. Of note, among pigs fed unconventional base diets (U and $\mathrm{UH}$ ) significantly $(p<0.05)$ lower crude fat was observed only in gilts. Meat of $m$. longissimus muscle from pigs fed diet $\mathrm{U}$ showed a significantly ( $\mathrm{p} \leq 0.05$ ) higher (by $\sim 7 \%$ ) WHC in comparison to pigs fed $\mathrm{C}$ diet. Our results on WHC are consistent with results reported by others (Mayoral et al., 1999; Hańczakowska et al., 2007; Ao et al., 2011).

In general, there is a paucity of information on the effects of feedstuffs on WHC. According to Kaczmarek and

Table 4. Physical and chemical properties of $m$. longissimus muscle

\begin{tabular}{|c|c|c|c|c|c|c|c|c|c|c|}
\hline \multirow{3}{*}{ Specification } & \multicolumn{6}{|c|}{ Treatment (Diet/sex) } & \multirow{3}{*}{ SEM } & \multicolumn{3}{|c|}{ Significance } \\
\hline & \multicolumn{2}{|c|}{$\mathrm{C}$ (Conventional) } & \multicolumn{2}{|c|}{ U (Unconventional) } & \multicolumn{2}{|c|}{ UH (U+herbs) } & & \multirow{2}{*}{ Diet (D) } & \multirow{2}{*}{$\operatorname{Sex}(S)$} & \multirow{2}{*}{$\mathrm{D} \times \mathrm{S}$} \\
\hline & $\mathrm{G}^{1}$ & $\mathrm{~B}^{1}$ & $\mathrm{G}$ & $\mathrm{B}$ & G & B & & & & \\
\hline WHC (\%) & 21.1 & 19.8 & 26.8 & 27.6 & 26.5 & 27.8 & 0.580 & 0.001 & 0.606 & 0.071 \\
\hline $\mathrm{pH}_{45}$ & 6.29 & 6.12 & 6.54 & 6.51 & 6.50 & 6.36 & 0.159 & 0.134 & 0.392 & 0.906 \\
\hline $\mathrm{pH}_{24}$ & 5.75 & 5.50 & 5.44 & 5.68 & 5.46 & 5.47 & 0.097 & 0.244 & 0.975 & 0.050 \\
\hline \multicolumn{11}{|l|}{ Colour } \\
\hline $\mathrm{L}^{*}$ & 50.7 & 47.6 & 49.3 & 47.8 & 49.2 & 48.4 & 0.861 & 0.674 & 0.054 & 0.215 \\
\hline$a^{*}$ & 8.1 & 7.9 & 8.5 & 7.5 & 6.9 & 8.0 & 0.327 & 0.233 & 0.642 & 0.135 \\
\hline $\mathrm{b}^{*}$ & 1.6 & 1.5 & 1.4 & 1.3 & 1.5 & 1.4 & 0.390 & 0.354 & 0.542 & 0.216 \\
\hline Crude ash $(\%)$ & 1.10 & 1.11 & 1.11 & 1.10 & 1.12 & 1.12 & 0.006 & 0.069 & 0.636 & 0.293 \\
\hline $\mathrm{CP}(\%)$ & $22.02^{\mathrm{a}}$ & $22.44^{\mathrm{ab}}$ & $22.96^{\mathrm{b}}$ & $22.47^{\mathrm{ab}}$ & $22.67^{\mathrm{ab}}$ & $22.47^{\mathrm{ab}}$ & 0.185 & 0.035 & 0.561 & 0.050 \\
\hline Crude fat $(\%)$ & $2.01^{\mathrm{c}}$ & $1.76^{\mathrm{bc}}$ & $1.55^{\mathrm{ab}}$ & $1.91^{\mathrm{c}}$ & $1.31^{\mathrm{a}}$ & $1.86^{\mathrm{bc}}$ & 0.101 & 0.018 & 0.008 & 0.001 \\
\hline
\end{tabular}

${ }^{1} \mathrm{G}=$ Gilts $(\mathrm{n}=8) ; \mathrm{B}=$ Barrows $(\mathrm{n}=8) .{ }^{\mathrm{a}, \mathrm{b}, \mathrm{c}}$ Means in columns with a similar letter did not differ $\mathrm{p} \leq 0.05$. 
Rząsa (2005), dietary inclusion of $8 \%$ to $6 \%$ fish meal in diet for growing/finishing did not influence WHC. The WHC of wild and breeding pigs is similar (Marchiori and de Felicio, 2003), however it is known that the pig breed influenced WHC (Ksobiak et al., 2005). Similarly to other authors (Peeters et al., 2006; Janz et al., 2007; Wang et al., 2007; Świątkiewicz and Hańczakowska, 2008; Simitzin et al., 2010; Ao et al., 2011) the present work showed no impact of herbs on WHC and meat $\mathrm{pH}$. Dietary inclusion of $1 \mathrm{~g}$ coneflower extract per $\mathrm{kg}$ diet decreased WHC of meat (Hańczakowska et al., 2007). Water holding capacity depends on the level of inter-muscular fat, as the capacity is lower when inter-muscular fat increases (Hankovaara, 1997; Joo and Kim, 1997; Rybarczyk et al., 2005), and this is consistent with the results of the present work. Notably, there was an increase in protein content and a slight reduction $(\mathrm{p} \leq 0.05)$ fat content in the $m$. longissimus in pigs fed diet $U$ amended with herbs (Table 4). Higher fat in pigs fed unconventional diet in the present study is in agreement with the results of Buczma (2000) who reported the effects of inclusion of potatoes in the diet. Lower fat levels in pigs may be also obtained by restrictive feeding (Cameron and Curran, 1995) and rationing (Kapelański et al., 2001).

Sensory analysis of $m$. longissimus (Table 5) showed that conventional feeding significantly affected only palatability $(\mathrm{p}<0.01)$ and tenderness $(\mathrm{p}<0.01)$. Improved meat palatability and tenderness in pigs fed unconventional diet parallels the effects on fat level in meat. The presence of inter-muscular fat results in meat marbling and loosens connective tissue, which positively influences the sensory attributes of meat (Wajda et al., 2004). In the present study, in general, the addition of herbs to the diet (UH) did not influence meat sensory attributes. Consistent with our observation, Grela (2000) reported no effects on ratings of aroma, juiciness, tenderness, and palatability of longissimus muscle from pigs fed diets supplemented with a six-herb mixture. However, other workers have demonstrated that an application of some herbs individually may have a varying effect on the sensory attributes. For example Echinacea Purpurea (Hańczakowska et al., 2007) significantly reduced meat flavour, tenderness and juiciness, whereas an addition of garlic ( $1 \%$ or $1.5 \%)$ significantly increased ( $7 \%$ to $11 \%$ ) juiciness (Omojola et al., 2009). Also, Świątkiewicz and Hańczakowska (2008) added herb mixtures to grass silage for pigs reported a significant improvement in the flavour and aroma of $m$. longissimus. It is likely that supplementation level of herbs in our study was insufficient to effectively influence the sensory attributes (Janz et al., 2007).

Lack of clear differences in BW, carcass length, ham and neck weight, and WHC, $\mathrm{pH}$ and meat colour, crude ash and $\mathrm{CP}$ content, and sensory attributes between gilts and barrows suggest that both sexes were similar in their response to all treatments.

Overall, the observed diet $\mathrm{x}$ gender interactions (Tables 3 and 4) indicated that the effects of diet on some carcass and meat quality measurements were dissimilar between the two sexes. It is noteworthy, however, that gilts had higher $(p<0.05)$ meatiness and loin eye area, but lower suet mass, thinner $(\mathrm{p}<0.05)$ layers of backfat, and lower $(\mathrm{p}<0.05)$ fat content in $m$. longissimus in comparison with barrows. Similar to the present work (group C), gender differences were reported by Eckert (2006), where in comparison to barrows, gilts had higher meatiness and loin eye area.

It seems that use of diet based on steamed potato-green forage-concentrate mixture was more effective in gilts than in boars in changing carcass quality.

\section{CONCLUSION}

Unconventional feeding (based on steamed potato-green forage-concentrate mixture) slightly decreased some post slaughter variables including meatiness, loin eye area, but increased carcass length, backfat and WHC. In comparison to conventional feeding, the unconventional feeding in pigs showed positive effects on sensory attributes of $m$. longissimus, in particular palatability and tenderness. Supplementation of unconventional diet with herbs reduced fat content in the $m$. longissimus and increased loin eye area. The responses to feeding systems (conventional vs

Table 5. Results of sensory evaluation of $m$. longissimus muscle (Scores)*

\begin{tabular}{|c|c|c|c|c|c|c|c|c|c|c|}
\hline \multirow{3}{*}{ Specification } & \multicolumn{6}{|c|}{ Treatment (Diet/sex) } & \multirow{3}{*}{ SEM } & \multicolumn{3}{|c|}{ Significance } \\
\hline & \multicolumn{2}{|c|}{$\mathrm{C}$ (Conventional) } & \multicolumn{2}{|c|}{ U (Unconventional) } & \multicolumn{2}{|c|}{ UH (U+herbs) } & & \multirow{2}{*}{ Diet (D) } & \multirow{2}{*}{$\operatorname{Sex}(S)$} & \multirow{2}{*}{$\mathrm{D} \times \mathrm{S}$} \\
\hline & $\mathrm{G}^{1}$ & $\mathrm{~B}^{1}$ & $\mathrm{G}$ & $\mathrm{B}$ & $\mathrm{G}$ & B & & & & \\
\hline Flavour intensity & 4.00 & 4.00 & 4.50 & 4.25 & 4.50 & 4.38 & 0.199 & 0.071 & 0.447 & 0.822 \\
\hline Flavour desirability & 4.38 & 4.00 & 4.50 & 4.25 & 4.50 & 4.34 & 0.183 & 0.372 & 0.102 & 0.793 \\
\hline Palatability intensity & $4.25^{\mathrm{a}}$ & $4.12^{\mathrm{a}}$ & $4.75^{\mathrm{bc}}$ & $4.63^{\mathrm{ab}}$ & $4.88^{c}$ & $4.87^{\mathrm{c}}$ & 0.149 & 0.001 & 0.498 & 0.890 \\
\hline Palatability desirability & $4.50^{\mathrm{abc}}$ & $4.13^{\mathrm{a}}$ & $4.75^{\mathrm{bc}}$ & $4.69^{\mathrm{bc}}$ & $4.88^{\mathrm{c}}$ & $4.88^{\mathrm{c}}$ & 0.154 & 0.003 & 0.193 & 0.471 \\
\hline Tenderness & 4.12 & 3.88 & 4.34 & 4.50 & 4.63 & 4.50 & 0.185 & 0.010 & 0.584 & 0.591 \\
\hline Juiciness & 4.13 & 3.89 & 4.25 & 4.00 & 4.50 & 4.38 & 0.182 & 0.057 & 0.168 & 0.924 \\
\hline
\end{tabular}

* From 1 (least favourable) to 5 (most favourable). ${ }^{1} \mathrm{G}=$ Gilts $(\mathrm{n}=8) ; \mathrm{B}=$ Barrows $(\mathrm{n}=8)$.

${ }^{a, b, c}$ Means in columns with a similar letter did not differ $\mathrm{p} \leq 0.05$. 
unconventional) with regard treatments to some carcass and meat measurements were dissimilar for gilts vs barrows. Feeding unconventional diet may offer better culinary attributes of the meat, and improve some technologically important characteristics of pig carcass, but may have negatively affected some parameters.

\section{REFERENCES}

Ao, X., Q. W. Meng, and I. H. Kim. 2011. Effects of fermented red ginseng supplementation on growth performance, apparent nutrient digestibility, blood hematology and meat quality in finishing pigs. Asian Australas. J. Anim. Sci. 24:525-531.

AOAC. 1990. Official Methods of Analysis. 15th ed. Association of Official Analytical Chemists, Arlington, VA.

Bee, G., C. Biolley, G. Guex, W. Herzog, S. M. Lonergan, and E. Huff-Lonergan. 2006. Effects of available dietary carbohydrate and preslaughter treatment on glycolytic potential, protein degradation, and quality traits of pig muscles. J Anim. Sci. 84:191-203.

Borzuta, K., J. Strzelecki, K. Dziadek, E. Grześkowiak, D. Lisiak, and P. V. Janiszewski. 2008. Comparison of slaughter value and meat quality of PEN-AR-LAN hybrid pigs and line 990. Rocz. Nauk. Zoot. 35:63-73. (in Polish with English abstract).

Bredahl, L., K. G. Grunert, and C. Fertin. 1998. Relating consumer perceptions of pork quality to physical product characteristics. Food Qual. Prefer. 9:273-281.

Bryhni, E. A., D. V. Byrne, M. Rødbotten, C. Magnussen, H. Agerhem, M. Johansson, P. Lea, and M. Martens. 2002. Consumer perceptions of pork in Denmark, Norway and Sweden. Food Qual. Prefer. 13:257-266.

Buczma, J. 2000. Slaughter value and meat quality of fattening pigs from different fattening and managment systems. Ann. Univ. Mariae Curie Sklodowska Sect. EE Zootech. 12:87-96.

Cameron, N. D. and M. K. Curran. 1995. Genotype with feeding regime interaction in pigs divergently selected for components of efficient lean growth rate. Anim. Sci. 61:123-132.

Carlsson, D., H. N. Lærke, H. D. Poulsen, and H. Jørgensen. 1999. Roughages for growing pigs, with emphasis on chemical composition, ingestion and faecal digestibility. Acta Agric. Scand. Sect. A, Anim. Sci. 49:129-136.

Cullen, S. P., F. J. Monahan, J. J. Callan, and J. V. O'Doherty. 2005. The effect of dietary garlic and rosemary on growerfinisher pig performance and sensory characteristics of pork. Ir. J. Agric. Food Res. 44:57-67.

Danielsen, V., L. L. Hansen, F. Møller, C. Bejrholm, and S. Nielsen. 2000. Production results and sensory meat quality of pigs fed different amounts of concentrate and ad lib. clover grass or clover grass silage. In: Ecological Animal Husbanddry in the Nordic Countries (Eds. J. E. Hermansen, V. Lund, and E. Thuen). Proceedings from NJF-seminar No. 303. Horsens, Denmark. pp. 79-86.

Eckert, R. 2006. Determination of the stock of pigs in a massive response to the selection carried out on the basis of lethal boar carcass evaluation. Ann. Anim. Sci. Krakow 34:2-4.

Grela, E. R. 2000. Effect of herbs on the carcasses of slaughter value and selected chemical and organoleptic characteristics of meat pigs. Ann. Anim. Sci. Krakow 6:167-171.

Grau, R. and R. Hamm. 1953. A simple method for the determination of water binding in muscles. Naturwissenschaften 40:29-30.

Hańczakowska, E., M. Świątkiewicz, and A. Szewczyk. 2007. Efficiency of herb preparation and garllic acid in pig feeding. Ann. Anim. Sci. 7:131-139.

Hankovaara, M. 1997. Evaluation of the frequency of RSE pork in Finnish slaughter pigs and its technological effects. In: Proceedings of the 43rd ICoMST, Auckland, New Zealand. pp. 296-297.

Janz, J. A. M., P. C. H. More, B. H. P. Wilkinson, and R. W. Purchas. 2007. Preliminary investigation of the effects of lowlevel dietary inclusion of fragnant essential oils and oleorisins on pig performance and pork quality. Meat Sci. 75:350-355.

Jentsch, W., M. Beyer, and L. Hoffmann. 1992. The energetic utilization of rations with steamed potatoes in growing swine. Arch. Tierernahr. 42:117-131.

Jin, Z., Y. X. Yang, J.Y. Choi, P. L. Shinde, S. Y. Yoon, T. W. Hahn, H. T. Lim, Y. K. Park, K. S. Hahm, J. W. Joo, and B. J. Chae. 2008. Effects of potato (Solanum tuberosum L. cv. Golden valley) protein having antimicrobial activity on the growth performance, and intestinal microflora and morphology in weanling pigs. Anim. Feed Sci. Technol. 140:139-154.

Joo, S. T. and B. Ch. Kim. 1997. Effect of backfat thickness and inframuscular fat $\%$ on color and drip loss of pork loin. 43rd ICOMST, New Zealand. pp. 568-569.

Kaczmarek, P. and A. Rząsa. 2005. Effect of diet containg fish meal on physicochemical and organoleptical properties of fatteners meat. Sci. Ann. Pol. Soc. Anim. Prod. 1,2:359-366. (in Polish with English abstract).

Kapelański, W., J. Falkowski, and A. Hammermeister. 2001. The effect of ad libitum and restricted feeding on performance, carcass composition and meat quality of pigs. Pol. J. Natur. Sci. 9:269-276.

Kim, B. C., C. Y. Han, S. T. Joo, and S. Lee. 1999. Effects of displaying conditions of retailcuts after vacuum packed storage on pork quality and shelf-life. Korean J. Anim. Sci. 41:75-88.

Krusiński, R. 2000. Effect of herbs on the effects of fattening pigs and meat quality. Ann. Univ. Mariae Curie Sklodowska Sect. EE Zootech. 35:269-277. (in Polish with English abstract).

Ksobiak, S., B. Rak, and H. Jankowiak. 2005. Comparison of carcass and meat quality traits of white pure-bred fatteners and crossbreds with contribution of Pietrain sires. Sci. Ann. Pol. Soc. Anim. Prod. 1:367-372.

Majewska, D., M. Jakubowska, M. Ligocki, Z. Tarasewicz, D. Szczerbinska, T. Karamucki, and J. Sales. 2009. Physicochemical characteristics, proximate analysis and mineral composition of ostrich meat as influenced by muscle. Food Chem. 117:207-211.

Mayoral, A. I., M. Dorado, M. T. Guillén, A. Robina, J. M. Vivo, C. Vázquez, and J. Ruiz. 1999. Development of meat and carcass quality characteristics in Iberian pigs reared outdoors. Meat Sci. 52:315-324.

Marchiori, A. F. and P. E. de Felício. 2003. Quality of wild boar meat and commercial pork. Sci. Agric. 60:1-5.

NZS. 1993. Nutrient Requirements of Swine (Normy Żywienia Świń. Wartość pokarmowa pasz). PAN Instytut Fizjologii i 
Żywienia Zwierząt, Omnitech Press, Warszawa. (in Polish with English abstract).

Omojola, A. B., S. S. Fagbuaro, and A. A. Ayeni. 2009. Cholesterol content, physical and sensory properties of pork from pigs fed varying levels of dietary garlic (Allium sativum). World Appl. Sci. J. 6:971-975.

Paschma, J., A. Kaczor, and P. Paraponiak. 2010. Evaluation of the possibility of improving the breeding environment of pigs receiving dietary herb mixture. Rocz. Nauk. Zoot. 37:179-186. (in Polish with English abstract).

Paschma, J. and M. Wawrzyński. 2007. Effect of using herbs in pig diets on growth parameters, carcass traits and dietetic value of pork. Pol. J. Natur. Sci. (Suppl.) 4:71-76.

Peeters, E., B. Driessen, R. Steegmans, D. Henot, and R. Geers. 2006. Effect of supplemental tryptophan, vitamin E, and a herbal product on stress responses and pork quality. J. Anim. Sci. 84:1827-1838.

Rosenvold, K., H. N. Lærke, S. K. Jensen, A. H. Karlsson, K. Lundström, and H. J. Andersen. 2001. Strategic finishing feeding as a tool in the control of pork quality. Meat Sci. 59:397-406.
Rybarczyk, A., R. Szaruga, and W. Natalczyk-Szymkowska. 2005. The level of intramuscular fat, depending on the characteristics and meat quality of fattening pigs hybrids after boars that were Pietrain breed. Annals of the Institute of Meat and Fat. 42/43:109-117.

Simitzin, P. E., G. K. Symeon, M. A. Charismiadou, J. A. Bizelis, and S. G. Deligeorg. 2010. The effects of dietary oregano oil supplementation on pig meat characteristics. Meat Sci. 84:670676.

Świątkiewicz, M. and E. Hanczakowska. 2008. Effect of herbs mixture and enzymes supplementation of a grass silage diet for pigs on performance and meat quality. Medycyna Wet. 64:782785.

Turyk, Z., M. Osek, A. Janocha, and B. Olkowski. 2011. Feeding diets based on barley or triticale during fattening of high-meat PIC pigs: Effects on carcass characteristics and meat quality parameters. Acta Vet. Beograd. 61:67-75.

Wajda, S., T. Daszkiewicz, and K. Borzuta. 2004. The quality of pig meat from carcasses of different weights. Sci. Ann. Pol. Soc. Anim. Prod. 72:185-191.

Wang, Y., Y. J. Chen, J. H. Cho, J. S. Yoo, Q. Wang, Y. Huang, H. J. Kim, and I. H. Kim. 2007. The effects of dietary herbs and coral mineral complex on growth performance, nutrient digestibility, blood characteristics and meat quality in finishing pigs. J. Anim. Feed Sci. 16:397-340. 